\title{
Tight Gas Potential Status, Obstacles and the Way Forward in Meeting Future Energy Needs of Pakistan
}

\author{
Aftab Ahmad Mahesar'a, Abdul Majeed Shar², Abdul Haque Tunio ${ }^{1 b}$
}

RECEIVED ON 05.04.2019, ACCEPTED ON 26.07.2019

\begin{abstract}
Production from unconventional tight gas resources plays significant role in energy market. It is commonly held that the tight gas has gained considerable importance in meeting energy needs and is widely developed across the world. It is also worth noting that several countries are engaged in pursuing the tight gas resources development to meet energy challenges. However, the copious concerns have emerged to technical and economic development of tight gas potential. Hence, it is essential to accurately assess the resources and to address the key technical issues and economic feasibilities that will support in mitigating the risk and to increase the investment opportunities. This paper provides a systematic review about current status, field development best strategies; in addition, the paper also addresses the obstacles and issues for development of tight gas potential in Pakistan. Although, the efforts made by the Exploration and Production (E\&P) firms operating in Pakistan are not very encouraging for tight gas resources development. Hence; this requires further improvements and accurate assessments to develop tight gas resources effectively. Thus, for accurate assessment of tight gas potential, various imperative approaches, ideas, considerations, several challenges and the best strategies for field development are highlighted that offers significant improvement in materializing the future trends in tight gas potential development. The paper will be a kind of helpful tool for the policy makers, potential investors and industry professionals working in Pakistan's E\&P industry.
\end{abstract}

Keywords: Tight Gas, Status, Development, Policy, Energy planning, Challenges.

\section{INTRODUCTION}

$\mathrm{T}$ he term "tight gas" has emerged for more than 30 years with debate on understanding the concept because of the diverse definition have emerged in different regions around the world $[1,2]$. Tight gas reservoirs could be classified based on their geological characteristics as; multi-layer lens, overlapped tight sand reservoir, multifaceted, complex tight gas sandstone reservoir and massive tight sand reservoirs [1]. Tight gas sands discovered in Pakistan are classified as massive sands found in the lower Indus Basin [3]. Tight gas reservoirs are considered to be marginally profitable gas accumulation that requires special treatments such as fracturing the formation to switch it on commercial production rates [4]. It has become inevitable to develop these resources to fulfill the present day energy requirements.

The tight gas has played significant role for economic and social development of many countries. It has gained considerable importance since decades in the energy market. Tight gas sands are widely developed across the world. Due to economic growth, the natural

${ }^{1}$ Institute of Petroleum and Natural Gas Engineering, Mehran University of Engineering and Technology, Jamshoro, Sindh, Pakistan.

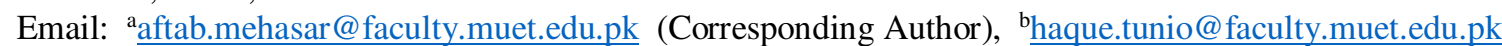

${ }^{2}$ Department of Petroleum Engineering, NED University of Engineering and Technology, Karachi, Sindh, Pakistan. Email: majeed@neduet.edu.pk

This is an open access article published by Mehran University of Engineering and Technology, Jamshoro under CC BY 4.0 International License. 
gas has gained considerable attention for the decades; many countries are pursuing the opportunities to develop unconventional natural gas resources [5]. Developed countries such as USA, China, and Europe have already addressed various concerns about the status, obstacles and have recommended practices for unconventional natural gas resources exploitation and development to overcome the energy crisis in different ways $[1,2,4,5]$. The illustration in Fig. 1 shows the status of unconventional natural gas production status from tight gas, shale gas and coalbed methane around the globe [6].

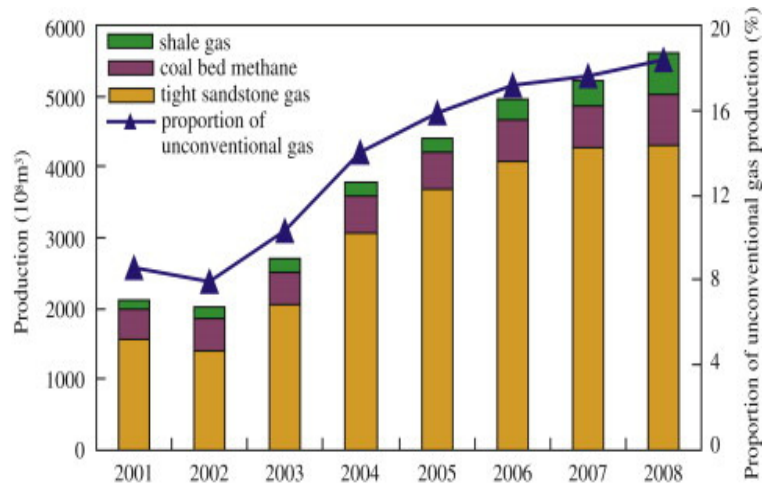

Fig. 1: Current Production Status of Unconventional Resources around the Globe [6]

Pakistan is developing country hence; there is a massive natural gas requirement in order to develop infrastructure. The escalated energy consumption due to power generating industrial sectors and other industrial units such as cement industry has also increased natural gas consumption and has resulted in increased demand of which is expected to reach to maximum up to 3542.9 Billion cubic meters in upcoming years [7-10]. The country only meets around $15 \%$ of fuel demand from indigenous oil production and the gas fulfills the $80 \%$ from indigenous production [3]. Hence, it could conceivably be hypothesized that such huge surge in energy may be the result of increased industrial units, urbanization and population growth. In particular, the industrial sector mainly uses the more natural gas to generate electricity; as well the gas is used for domestic purpose. Though, the resulting increase in energy consumption due to growing population and increased economy and industrial sectors has resulted annual deficit of around 8-9\% [11-14]. Additionally, the natural gas demand and supply gap has increased due to the declining of conventional reserves of the country [15]. The current and projected supply and demand status of Pakistan along with deficit is highlighted in Fig. 2 [16].

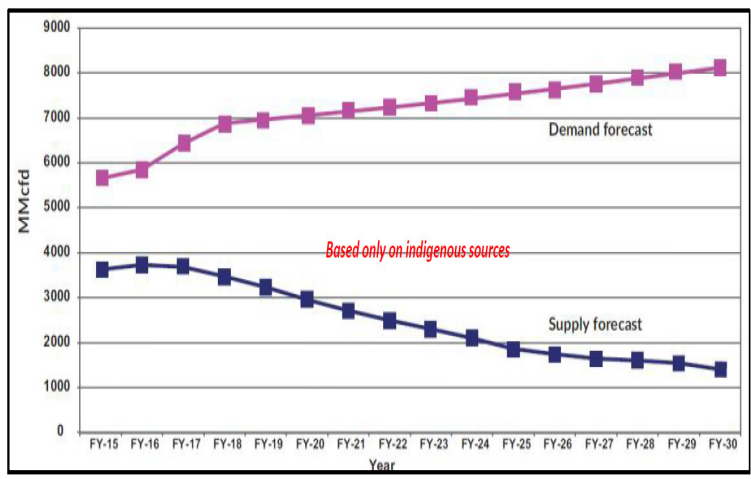

Fig. 2: The Demand and Supply Forecast of Pakistan [16]

As illustrated in Fig. 2, the projected deficit of natural gas requirements are expected almost to twofold in early years e.g. 2010, more recently it has shown large surge of demand. On the contrary, other energy sources such as coal and hydropower have emerged to compensate the present day need as country is in its developing stage. Although, these resources contribution is very insignificant for Pakistan's energy needs. Moreover, there have been several studies emerged and have suggested that the sustainable development of unconventional resources could help in alleviating the natural gas shortfall, and balance the demand and supply gap [17-20]. Fortunately, the country has blessed with enormous unconventional natural gas resources [21, 22].

It is commonly held that the developing and promoting indigenous tight gas resources would be more realistic and feasible option than import. Pakistan possesses enormous reserves of tight gas comprising around 40 Trillion Cubic Feet (TCF) [20-22]. Due to the fact that such significant tight gas reveres of country exists in tight formations and is believed to be enough to meet the future energy requirement. However, the natural gas industry faces many challenges such as investments, sustainability, environmental concerns, lack of financial subsidies and gas pricing.

Pakistan's current natural gas demand deficit is about 1.5-2.5 Bcf/d [16]. In upcoming years, the deficit of 
gas will be fulfilled by injecting the Liquefied Natural Gas (LNG) to meet the domestic needs. The government of Pakistan has considered the gas import option (3.5 million $\mathrm{mt} /$ year of LNG to meet the energy deficit [23]. The import option is not appropriate for the country's economy, due to the fact that recoverable tight gas reserves are quite high to be developed to fulfil the energy needs. Though, the gas import option will require large capital investment that will eventually result into a higher gas prices to the endusers. Hence, to overcome the energy deficit, to maintain the energy security and to provide the sustainable supply of gas, it is far better to un-tap the hidden tight gas potential. Unfortunately, the E\&P companies working in Pakistan currently are very reluctant to make investments on tight gas resources due to the huge capital investment requirements for resources development and increases risk factor hinders the development [20]. However, Ministry of Petroleum and Natural Resources (MNPR) has envisioned with its first policy on "Tight Gas (Exploration and Production) Policy, 2011", to encourage the industry to produce the gas from such reservoirs granting with some incentives [24]. However, the existing "Tight Gas policy, 2011" needs further revisions in order to encourage unconventional gas resources development in Pakistan. It was recommended that the existing tight gas policy of Pakistan "Tight Gas (Exploration and Production) Policy, 2011" will be revised after every two years. Unfortunately; no amendments has been made to date. Although, for successful development of tight gas resources, it is essential that the Directorate of Petroleum Concessions Concerned Department (DGPC) and MNPR have to play a pro-active role in introducing a series of tight gas industry policies and development plans. Pakistan's Tight Gas (Exploration and Production) Policy, 2011 [24] mainly lacks the finance and tax policy, technology R\&D support policy, resources management policy and pipelines network policy and international cooperation policy. Apart from policy design, the industry is facing various other challenges in particular to foreign investment companies. Such as, the foreign investors are concerned over investment security to develop tight gas resources. Other obstacles that are being faced by the foreign investor starts from the exploration to development includes the uncertainty and security threats, problems due to local community hindrances, access to location, policy implementation problems, technical problems and insufficient infrastructure, all collectively confines Pakistan's E\&P industry to develop its tight gas potential effectively. These are the essential issues that necessitate to be addressed appropriately and the policy revisions will provide a clear understanding about the scenarios prior to investments.

This paper has presented review by examining the recent information on the status, obstacles, policies, procedures and techniques involved for tight gas resource development. More specifically the paper has highlighted the several ideas, approaches tended to encourage the E\&P companies to develop tight gas potential by making technical decisions. The overall structure of the study takes the form of different sections, including this introductory section; section 2 discussed about Status of tight gas potential development in Pakistan, section 3 Exploration and production policy of country with special focus on tight gas exploitation and the way forward, section 4 addresses the Tight gas field Development best practices, section 5 status of key technology in tight gas potential development, section 6 obstacles and challenges, and possible future trends, Section 7 Scientific and economics evaluation techniques for tight gas development, section 8 summarizes the review by providing conclusion and emphasizes the important work.

\section{CURRENT STATUS OF TIGHT GAS POTENTIAL DEVELOPMENT}

Pakistan strategically covers large sedimentary basin which are spread over both on shore and offshore territories of the country [25, 26]. Fortunately, the country is blessed with enormous potential of indigenous unconventional natural gas potential throughout various basins i.e. Indus basin and Balochistan basin of the country $[15,20,25]$. The former is presently producing however; the latter has not shown any discovery yet; although it is believed that Balochistan basin is to be very prospective area [26]. Unfortunately, Balochistan basin has many geological and regional complexities, uncertainties such as varying concentration of mineral constituent,

Mehran University Research Journal of Engineering and Technology, Vol. 40, No. 3, July 2021 [p-ISSN: 0254-7821, e-ISSN: 2413-7219] 
rock properties heterogeneities that are currently deterring to develop tight gas resources within this basin [26]. Huge reserves of tight gas exists in Pakistan although the first success reported in regard to tight gas discovery and the well brought on production was the Sujawal Sindh, that was very significant breakthrough for the development of indigenous tight gas potential for the country [27]. These discoveries led to be the most striking for tight gas resources future development as well as in meeting energy requirement by expediting the tight gas production. It is interesting to note that Pakistan is bestowed with massive reserves of unconventional shale gas and tight gas both, the shale gas reserves are105 TCF and about 40 trillion cubic feet of tight gas $[15,20]$. Since, the reported unconventional resources of country were based on the collaborative surveys conducted by USAID and International Energy Agency (EIA) assessment and are totally based on their predictions [19, 20]. Recently Alam [20] has discussed about the challenges and strategies to promote the tight gas resources development in Pakistan and has reported that the tight gas potential of country is estimated to be in the range of 24-40 TCF. Together these studies provide important insights into the tight gas resources and are widely cited by many researchers $[4,20,28]$. These results related to tight gas potential are very encouraging. However, it is highly recommended that for further refinements more research on tight gas reserves assessment needs to be undertaken.

Moreover, the field-wise status, figures and facts of tight gas resources in Pakistan are provided below in Table 1 [20]. The Fig. 3 illustrates the projected tight gas and shale gas production. Exploration and production (E\&P) companies operating in Pakistan have been issued licenses to explore and to develop the tight gas potential of the country [23]. The state owned companies involved in exploration and development of $\mathrm{n}$ tight gas resources are Pakistan Petroleum Limited (PPL) and Oil and Gas Development Company Limited (OGDCL) along with joint shareholders. The tight gas reserves have also been reported within the prevailing Development and Planning leases [25,28-29]. There are several fields that have been discovered and are declared as tight gas fields their reserves and production status is shown in Table 1 [25]. One such example of tight gas potential is the recent discovery of PPL in the lower Indus basin of Pakistan [3]. After successful drilling and testing of the well Naushahro Feroze X1 (NF X-1) was declared and confirmed by the company as tight gas potential [29]. In addition to this successful discovery PPL has showed interest in drilling additional wells in prevailing development production leases [3].

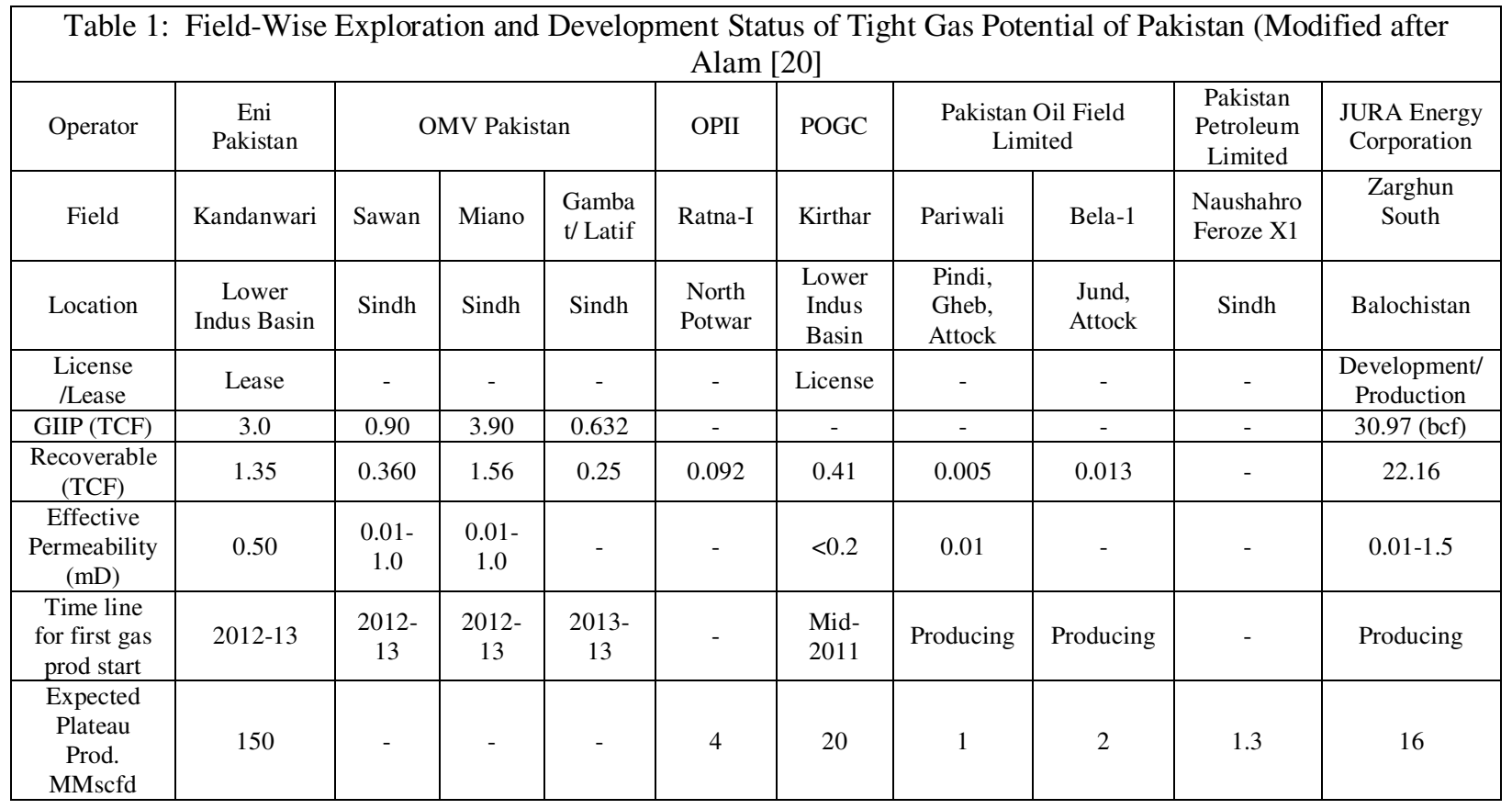




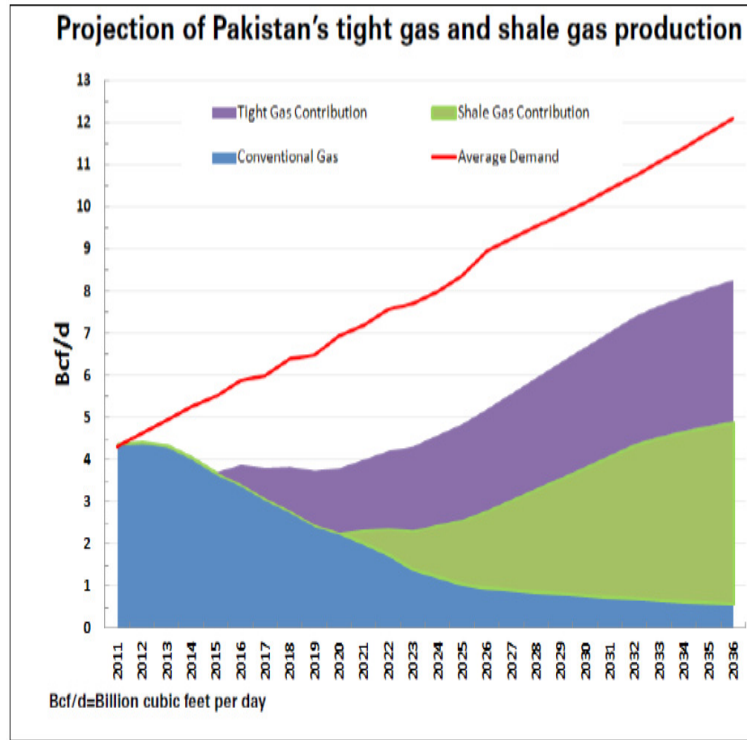

Fig. 3: Status of Tight Gas and Shale Gas Projected Production along with Production from Conventional Gas Reserves of Pakistan [16]

The Zarghun South gas field operated by Jura Energy Corporation discovered and declared it as a tight gas field was another recent past success $[28,30]$. The field was declared as tight gas field following the guideline provided by Pakistan's Tight Gas (E\&P) Policy, 2011. The discovered field is located in the Balochistan province of Pakistan some forty kilometres away from the province capital of Quetta. The area lies under the planning and development lease covering the three districts including Mastung, Dadhar, and Sibbi. The tight gas reserves reported are discovered in Lower Goru Tight Sands, Sembar Sands and Siltstones, Sui Upper Limestone, Habib Rahi Limestone and Pirkoh Limestone [20]. The reserves of the Zarghun South field contain fractured formations having low matrix porosity and permeability of carbonate reservoirs comprising of the Chiltan, Mughalkot and Dunghan formations [28, 29]. It is commonly held that aforementioned rock formations are the possible candidates for tight gas resources. Fig. 4 illustrates the total known tight gas resources of the country [25]. The Zarghum tight gas discovery was the recent reported success of the industry and the gas sale from Zarghun South field is $~ 16$ MMSFD, which has already started producing [28, 29]. More recently reported that the companies that are actively involved in exploitation and discovery of tight gas are Eni, PPL,
Orient Petroleum (OP), Polish Oil and Gas Company (PGNIG), Pakistan Oil Field Limited (POL). The OMV Pakistan now the United Energy Limited (UEPL) operating in Sawn and Miano fields discovered gas from tight potential of country and are production since year 2012-2013 [20]. Apart from Zarghum's tight gas discovery, the country has many other reported successful discoveries of the gas from tight potential including the Eni, Pakistan's Kandanwari, Sawan and Miano gas field of lower Indus basin with initial gas in place of around 4.0 TCF [20].

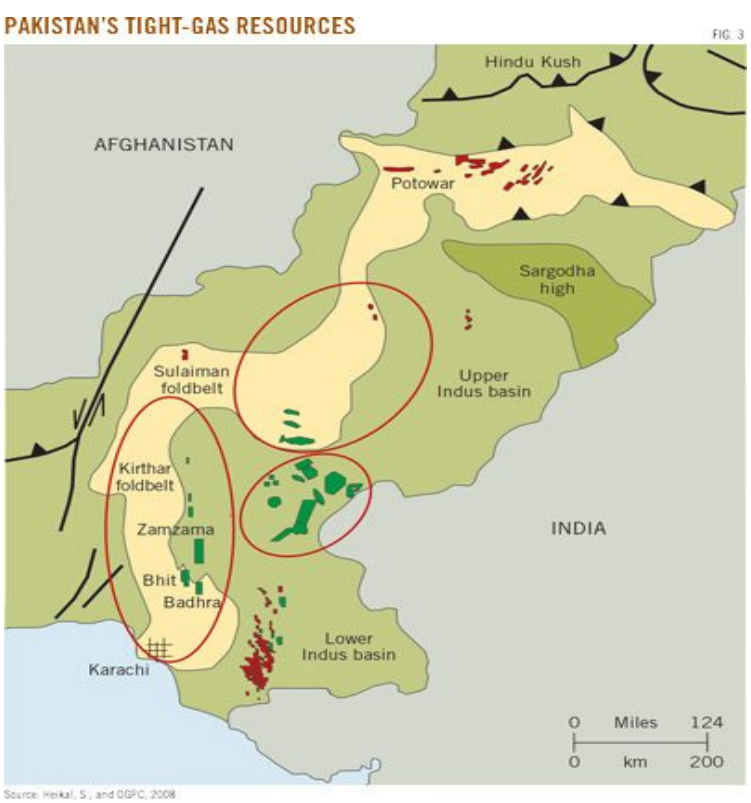

Fig. 4: Pakistan's known Tight Gas Potential shown from Geological Perspectives, The Area on Map is encircled representing its existence in different basins [24]

\section{EXPLORATION SCHEMES UNDER PAKISTAN'S PETROLEUM EXPLORATION AND PRODUCTION POLICY AND THE WAY FORWARD}

The companies involved in exploration of oil and gas reservoirs including tight gas generally follow the Pakistan Petroleum \& Exploration Policy (Table 2). The E\&P companies activities are divided into fourphases from E\&P and development based on the Pakistan's petroleum policy, 2012 [24]. Following discussion excludes the descriptions related to 
offshore areas with the application of the following defined time domains:

- Phase-I: Reconnaissance Permit, three years

- Phase-II: Petroleum Exploration License Onshore, five years, plus two renewals of one year each

- Phase-II: Market survey and confirmation, 2 years; plus 2 year extension

- Phase-III: Development and Production Lease, 25 years of period

- Phase-IV: Production period of 25 years.

The licensing of concessions are allocated based on competitive bidding process which will be open to all companies including national and multi-national companies, without any kind of government involvement and the foreign companies have no compulsion to take on board to national/domestic partners. Conversely, Pakistani companies can go for potential joint ventures with foreign investing companies. Tight gas producing companies would have the opportunity to sale out their produced gas to the local market at prevailing conditions of market prices. However, the incentives will only be applicable to tight gas reservoirs encountered within tight formations that qualify and are believed to be as "tight gas" under the defined terms and conditions of Tight Gas policy in prevailing and forthcoming exploration licenses, granted by Petroleum Concessions Agreements (PCAs) and Development \& Production (D\&P) leases [24]. One of the most significant progresses is that the government has decided to grant an extensive lease period to promote the tight gas with some exceptions of implications of taxes. However, to encourage the E\&P companies to speed up the development \& production from such low permeability reservoirs it is essential to the government of Pakistan provides an additional premium of $10 \%$ only for those wells which are brought on production in 2 years of announcement of tight gas policy, 2011 [24]. This 10\% premium for the companies working in exploiting tight gas resources is quite low. Hence, this should be revised by considering company circumstances investing in exploring tight gas potential. If any company would not get success then there will be an exit option at the end of Phase-II to relinquish. Furthermore, if company requires further leases then additional area could be granted subsequently. Pakistan's first “Tight Gas (E\&P), Policy, 2011" which provides only the definitions of tight gas resources with some development considerations. Further some guidelines for E\&P companies are provided despite its limitations that if any company is granted with license for development of tight gas resources that has to comply with commerciality, assets declaration and gas pricing [24]. However, the tight gas policy, 2011 lacks by financials and tax considerations, technology Research and Develop Fund (R\&D) to support the technology innovations, advancements, resources management policy, integrated energy policy and pipelines network policy, national and international institutional co-operations.

\subsection{The Way Forward}

The current circumstances are inevitable to exploit the unconventional tight gas resources. The policy makers and planners seem to be failed to arrange adequate energy requirement that is needed to fulfil the high growth rates in population and economy for the recent past decades. The country possesses enormous indigenous energy potential. The growing population and energy requirements were neither analyzed nor managed according to energy sector reform plans. Keeping in view of energy deficit and the complexities that occurred due to mismanagement of resources, some measure must have taken into account in order to resolve the crisis. However, short sightedness, incompetent governments and temporary arrangements on adhoc based policies to provide with rapid fixes, solutions in the choice of energy and technology have put the nation in darkness. Moreover, unwise decisions in supply of gas for power generation nevertheless of their unnecessary financial burden; illogical resources allocation, irrational supply of gas, poor policies on gas pricing, mismanagement of existing resources, lack of technical and skilled workers, inefficiency and resources mismanagement, operational mismanagement, bad governance and concerned institutional issues all are accountable to the present scenario of energy crisis. This can be dealt by accurate energy estimations as per growing population leading to impressive suggestions, guidance and new directions for policy makers to develop decisive policy by modify the existing polices on energy policies for the successful development of tight gas potential. 


\begin{tabular}{|c|c|c|c|c|}
\hline No & \multicolumn{4}{|c|}{ Table 2: Different types of E\&P rights for the Companies working In Pakistan Working Entire [31] } \\
\hline 1. & Phase-I & $\begin{array}{c}\text { Reconnaissance } \\
\text { permit }\end{array}$ & $\begin{array}{l}\text { Non-exclusive right for } \\
\text { geophysical, geochemical \& } \\
\text { geological operations, including the } \\
\text { drilling of stratigraphic wells. }\end{array}$ & $\begin{array}{l}\text { Initial time period is of one } \\
\text { year and could be extendable } \\
\text { for another one year. }\end{array}$ \\
\hline 2. & Phase II & $\begin{array}{l}\text { Onshore } \\
\text { Exploration } \\
\text { license }\end{array}$ & $\begin{array}{l}\text { Exclusive right for exploration, as } \\
\text { well as drilling and production } \\
\text { testing, as per specified terms } \\
\text { defined in license, rules and related } \\
\text { agreement. }\end{array}$ & $\begin{array}{l}\text { The time frame is initially } \\
\text { allowed five years (Phase-I } \\
\text { of } 3 \text { years and Phase-II of } 2 \\
\text { years) in addition two } \\
\text { renewals of each one year is } \\
\text { allowed. }\end{array}$ \\
\hline 3 & Phase III & $\begin{array}{l}\text { Development and } \\
\text { Production Lease }\end{array}$ & $\begin{array}{l}\text { The investor possesses an exclusive } \\
\text { right to develop and produce oil } \\
\text { \&gas from assigned part of a } \\
\text { Petroleum and Exploration License, } \\
\text { issued while satisfying the } \\
\text { conditions and rules. }\end{array}$ & $\begin{array}{l}\text { The time frame allowed is } \\
\text { up to } 25 \text { years with an option } \\
\text { of renewal for next five } \\
\text { years. }\end{array}$ \\
\hline 4. & Phase IV & $\begin{array}{c}\text { Petroleum } \\
\text { Exploration } \\
\text { License - Offshore } \\
\text { Shallow Water }\end{array}$ & $\begin{array}{l}\text { Investor has complete right for } \\
\text { exploration, including drilling and } \\
\text { production. }\end{array}$ & $\begin{array}{l}\text { Initial time domain is five } \\
\text { years (Phase-I of } 3 \text { years and } \\
\text { Phase-II of } 2 \text { years) and } \\
\text { could be extendable for } \\
\text { another one year. }\end{array}$ \\
\hline 5. & Phase IV & $\begin{array}{l}\text { Development and } \\
\text { Production Lease }\end{array}$ & $\begin{array}{l}\text { In this phase, the investor also } \\
\text { possesses an exclusive right to } \\
\text { develop and produce oil \&gas from } \\
\text { assigned part of a Petroleum and } \\
\text { Exploration Licence, issued while } \\
\text { satisfying the conditions and rules. }\end{array}$ & $\begin{array}{l}\text { The time frame allowed is } \\
\text { up to } 25 \text { years with an option } \\
\text { of renewal for next five } \\
\text { years. }\end{array}$ \\
\hline 6 & Phase V & $\begin{array}{c}\text { Petroleum } \\
\text { Exploration } \\
\text { Licence - Offshore } \\
\text { Deepwater and } \\
\text { Ultra Deep Water }\end{array}$ & $\begin{array}{l}\text { In this the investor has given } \\
\text { exclusive right to exploration, as } \\
\text { well as to drill and to produce and } \\
\text { to test along with production share } \\
\text { agreement (PSA). }\end{array}$ & $\begin{array}{l}\text { Time domain for this phase } \\
\text { is initially for five years and } \\
\text { is renewable for another one } \\
\text { year. }\end{array}$ \\
\hline 7 & Phase VI & $\begin{array}{l}\text { Development and } \\
\text { Production Lease }\end{array}$ & $\begin{array}{l}\text { In this phase the investor also } \\
\text { possesses an exclusive right to } \\
\text { develop and produce oil \&gas from } \\
\text { assigned part of a Petroleum and } \\
\text { Exploration Licence, issued while } \\
\text { satisfying the conditions and rules. }\end{array}$ & $\begin{array}{l}\text { The time frame allowed is } \\
\text { up to } 25 \text { years with an option } \\
\text { of renewal for next five } \\
\text { years. }\end{array}$ \\
\hline
\end{tabular}

\section{TIGHT GAS FIELD DEVELOPMENT BEST PRACTICES}

The exploitation and development techniques, practices and economic conditions emerged in different regions of the world are different $[1,19]$. The tight gas field development involves the high-level technology and huge capital investment, thus enabling the success of many of tight gas discoveries in Pakistan is the result of various motives, among these one of the fundamental reason is the regional geology and accessible natural land conditions which are very favorable for tight gas resources development. Optimizing the development plans are critical and require much devoted team of well experienced geologists, petroleum engineers. In order to identify the key parameters such as optimum, number of wells required, drilling and completions strategies for each well and development plans necessities experienced professionals of the specialized field. The key parameters and best practices that are necessary for the ght gas reservoirs development are presented in Fig. 5. 


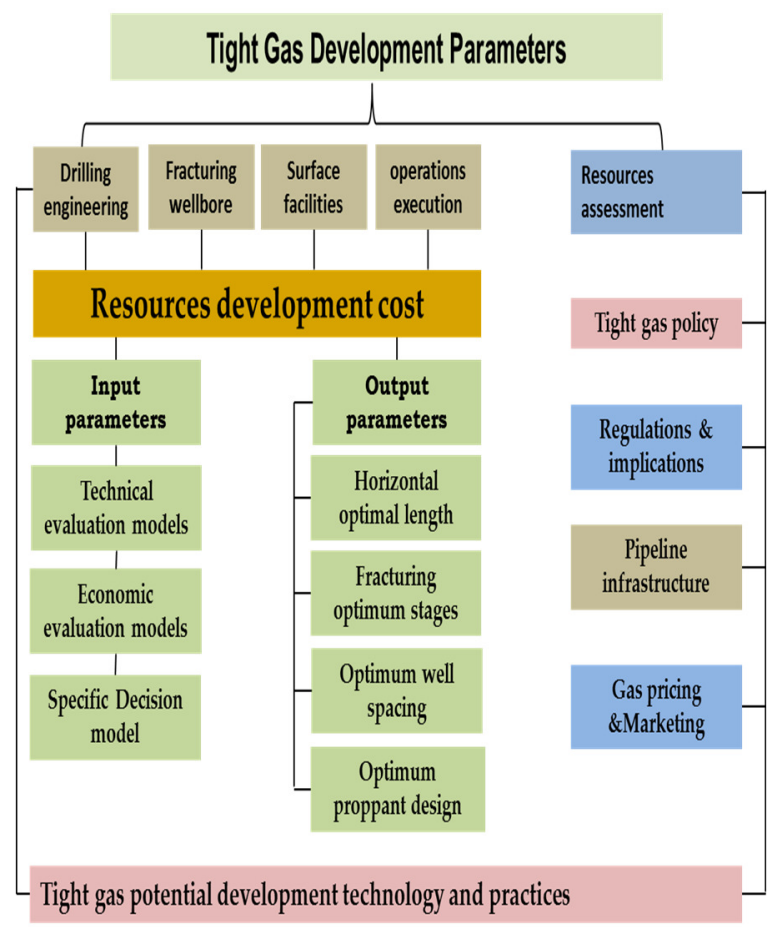

Fig. 5: Key Considerations for Tight Gas Potential Development

More recently, the advancements in technology of unconventional resources have discovered the gas potential that found to be present in nano-sized pores of tight sandstones mainly found in china [1-4]. Similarly, the tight gas resources exploitation in Pakistan requires advances techniques for detection of gas bearing formations which can result into increased success ratio in drilling new ventures. Additionally, the progress has been reported on well multi-layer sand fracturing technique that need to be adopted to effectively develop these resources tending to put on production to commercial rates. The economics of the existing wells and fields could be increased by drilling horizontal wells to maximize the exposure to formation and multistage fracturing of these formations. In Pakistan there is a single example of such practices but it is common practice in advanced countries for developing tight gas reservoirs. Furthermore, it is essential for field development to focus on the key constraints such as cost reduction this could be achieved by reducing cost of various drilling operations related by optimizing the well plans and decreasing the drilling rig time by improving rate of penetration. This will further help in reducing the all other associated cost of development from casing tools installation and cementing and fracturing and mud usage. All aforementioned measures could result into effective overall project cost reduction and marginally profitable field development.

\section{STATUS OF KEY TECHNOLOGY IN TIGHT GAS POTENTIAL DEVELOPMENT}

Pakistan has a complex geological structure in some parts of region that requires very specific tool to be either designed or import to optimize the gas production from such low quality reservoirs. The key tight gas technologies and equipment are not available in Pakistan; these are mostly imported from Dubai, China, USA, UK, Germany and Malaysia etc. through the competitive bidding process. None of the Pakistani firm has shown interest to develop drilling rigs indigenously and other associated necessary tools required for the tight gas industry. The import cost of such equipment and technology involvement from outside Pakistan has resulted in increased cost and very small benefit for the country leading to very high exploration and development cost. Additionally, the technology for tight gas resources exploitation and development has become common in most of the advanced countries such as US, UK, Canada, China etc. [1,4]. However, Pakistan yet imports most the equipment required for tight gas field development. The government of Pakistan should have to take initiative to focus on equipment manufacturing technology by carrying out technical research related to exploration and development of tight gas resources of country. Advancement in key technologies is essential and is challenging related to drilling horizontal wellbore trajectories, deflection control tools, fracture detection, designs of wellbore deviation, and other essential equipment that are crucial for drilling and controlling directional wellbore trajectories. Even though, there is not much laboratories that could derive the analysis related to petrophysical of properties of tight gas such as coring and conducting special core analysis, and other experiments that are necessary for developing tight gas resources. In this regard Pakistan has to focus and to make advancement in facilitating by provision of such technologies. 


\section{CHALLENGES AND OBSTACLES}

Strategic planning for tight gas resources development is one of the most challenging tasks in exploiting the resource after geophysical, geological and petrophysical analysis. Development of tight gas fields need different levels of technology, expertise and investments than the conventional gas fields to unlock the potential that could result in commercial production and increase in economics [14, 29, 30]. The main challenges faced by the tight gas industry to enhance the exploitation to optimize the energy mix and reduce the dependence on import the three key area to be focuses (i) Strategic Approach (ii) Technical and economical expertise (iii) Tight Gas policy and prices.

Lack of Strategic Approach: Energy crisis faced by the nation is due to lack of many flaws such as policy, adhoc based arrangements and careless in decision makings. The current scenarios may take in to such gruesome condition in the presence of valuable natural gas resources. This might have_some negative impacts by prioritizing the use of gas, as a result taking advantage by earning more benefits. However, much of the research up to now has extensively discussed that the early era in Pakistan history was remarkable from 1960-1970s during these years, the priority for gas supply was given mostly to industries such as cement and fertilizer sector; conversely, slow addition of domestic consumers emerged and large growth in power sector by generating electricity has changed the priorities [32]. All these past poor practices and ignorance have resulting into present crisis of energy and its management.

Technical and Economical: Tight sand gas reservoirs in Pakistan found are usually massive sands [29], with low primary porosity and permeability. Hence these reservoirs considerably require drilling denser vertical and horizontal wells and massive fractured treatments tended to be multistage. The first such successful operation on Pakistan's tight gas reservoirs has been reported by state owned company PPL on its NFX-1 well [29]. Most studies suggested to drill dense well for tight gas field development, all operating procedure and development guidelines in particular the china, USA, and UK have been highlighted in literature [18-19] if followed will improve the efficiency. Although the drilling a single vertical well would not tend to be profitable. Thus the successful commercial production could be achieved by drilling infill wells. Although Pakistan lacks in advanced technology to more wells and fracturing will increase ultimate cost of development. In addition, there is very limited petrophysical data on kirthar fold belt tight gas potential of Pakistan is present in public domain, more measurements will be provde support in better resources assessment $[15,34]$.

Incentivize Investment and Gas Pricing Considerations: Additionally, the gas pricing is critical steps in development of tight gas resources. It was decided under the tight gas policy of Pakistan, 2011 that the companies discovering and developing the tight reservoirs in Pakistan will be offered with incentives. Moreover, the allocation of incentives to companies to be granted based on well-defined boundaries. If companies are taking longer period to produce than the allocated time frame from tight gas resources than the companies will be bound to sale their gas at reduced rates. Hence, such uncertainties lie under the policy and are discouraging to E\&P companies to invest their capital on such low permeability reservoirs. Moreover, inappropriate pipeline network for the tight gas and relevant infrastructure is also a big issue. Government is obligated to revise the policy and to provide with clear strategic plan for the companies to develop and to untap the hidden energy potential to overcome the energy crisis of the country. In addition, it has been argued that the reported geological and other associated data and reserves assessments to tight gas resources are yet immature requires further accurate resources evaluation [33, 34]. Though, it is highly recommended that there must be systematic tight gas potential resource analysis in order to provide public or the investor with reasonable authenticity. This could be done by taking on board to different stakeholders, industry and academician experts would be brought together to collect the all relevant data on tight gas potential and to analyze more appropriately.

\subsection{Environmental Concern}

Environmental protection agency plays significant role on controlling and assessing the hazards that may harm the environment. In petroleum industry, there are 
certain different stages where environmental issues might happen in tight gas resources exploration and production hence, the establishment of environmental supervision is necessary. The initial stage of environmental risk assessment and supervision of the complete process of tight gas exploration and development is to be established during the whole process that comprises the series of job and their careful monitoring from seismic surveys, for drilling rig installation, wellsite preparation and selection of equipment and transportation for drilling at rig-site. In addition, many other operations need considerable environmental attention prior to any activity such as well drilling operations, cementation processes, well casing, and hydraulic fracturing treatments. The fracturing job requires water in huge quantity, hence supply of water and its uses must be monitored, air emission is also the major concern, solid waste management and wellsite closure and reclamation, though the supervision of tight gas well site closure and reclamation is essential.

\section{SCIENTIFIC AND ECONOMICS EVALUATION TECHNIQUES FOR TIGHT GAS DEVELOPMENT}

The key technologies and equipment required to develop tight gas resources in Pakistan are all imported from US, China, and Dubai and Canada etc. Hence, this has resulted in very marginal benefit for the country's E\&P companies in developing the tight gas potential and has led to very high exploration and development expenditures. As per our knowledge the unconventional gas resources exploitation technologies for the other developed countries such as china and Canada are still at their market promotional stage, while Pakistan have not focused to make investment in order to develop the equipment or the techniques that are necessary for development of the tight gas potential of the country. This requires strong base of technical knowledge and research that help will in developing these resources efficiently.

Apart from importing key technologies for tight gas exploitation government should convince the foreign companies to develop and to make the tools required for the drilling horizontal wellbore trajectory and controlling, detecting fracture orientations, etc. as well as other crucial equipment and tools. Pakistan still lacks in developing such infrastructure and it requires advancements and innovations in technology as per complex geological conditions of the region to handle the challenges involved more effectively.

\section{POLICY RECOMMENDATIONS}

Many countries around the globe have introduced new policies and recommended procedures to promote the tight gas development in their countries. Similarly, Pakistan must have to make reforms by introducing new policies in order to encourage the development of tight gas resources more efficiently. The reform tended to be economic incentive by considering the following technical measures:

(i) Exploring tight gas requires huge capital investments hence, financial subsidies provision is essential and is required,

(ii) Tight Gas exploration is highly technical and requires large investment thus exploration and development of unconventional resources should be initiated by the joint exploration and development effort. The idea of joint exploration and development would integrate different domain and to execute different possible operations simultaneously to succeed in exploitation of numerous tight gas fields.

(iii) Current energy crisis are due to the deficiency in development of strategic approach, hence that could be overcome by devising concrete tight gas policy by prioritizing the usage of natural gas for industrial sector. Further the natural gas is considered to be the greener fuel hence, should be given more importance than other fossil fuels such as coal and crude oil.

(iv) The government should facilitate E\&P Companies desiring to develop the Tight Gas resources of country by yielding concession blocks through transparent and merit based processes. In addition, the government should consider companies request in allocating more time periods not exceeding 10 years. 
(v) Promoting gas price reforms are recommended by offering modest well-head gas prices that will inspire new tight gas exploration ventures that will eventually turn into increased ultimate gas production.

(vi) MNPR should yield tax concessions, exemption and tax rebate.

(vii) It is also recommended that government should allocate research funding for appropriate assessment and development of the resources.

(viii) More specifically, the reasonable extension in time periods is recommended in order to make more investments on development of tight gas potential.

(ix) It is also recommended to devise an integrated energy policy with focus on exploration and development of low carbon emitting fuels i.e. tight gas resources for energy requirements. Although the existing Tight Gas policy, 2011 of Pakistan is old and it requires amendments as described.

\section{CONCLUSION AND RECOMMENDATIONS}

The tight sand gas reservoirs have emerged more recently in Pakistan and are in development stage; therefore, certain challenges still exist in order to develop resource effectively. However, the present study reviews has highlighted key points that could further enhance tight gas resources development for upcoming years. In summary,

(i) Developing marginally profitable tight gas reservoirs one of the most significant things to be considered is the paradigm shift of technology.

(ii) An integrated energy policy to be developed by taking account of all essential technologies as highlighted and emphasized in this paper to exploit the resource more effectively is to be considered.

(iii) Joint exploration and development effort is needed through integrated approaches, methodologies and operating techniques to become successful in developing tight gas reservoirs. In this way, the aggravating intervention between the different troubles makings will be minimized leading to enhanced gas production from tight gas reservoirs.

(iv) Promote tight gas resources development and to encourage exploration \& production companies by incentives provision and revising existing polices.

(v) It is highly recommended that the best strategies and best practices as described in paper must be followed to become successful in resource development efficiently.

\section{REFERENCES}

1. Xinhua M., Ailin J., Jian T., Dongbo H., "Tight Sand Gas Development Technology and Practices in China", Petroleum Exploration and Development, Vol. 39, No. 5, 611-618, 2012.

2. Holditch S. A., "Tight Gas Sands", Journal of Petroleum Technology, Vol. 58, No. 06, pp, 8693, 2006.

https://www.ppl.com.pk/EP_Brochure_Oct_201 6.pdf, [Last accessed on $4^{\text {th }}$ March, 2019].

3. Ma Y. Z., Moore W. R., Gomez E., Clark W. J., Zhang Y., "Tight Gas Sandstone Reservoirs, Part 1: Overview and Lithofacies", Unconventional Oil and Gas Resources Handbook, pp, 405-427, Gulf Professional Publishing, 2016.

4. Yuan J., Luo D., Feng L., "A Review of the Technical and Economic Evaluation Techniques for Shale Gas Development", Applied Energy, Vol. 148, pp, 49-65, 2015.

5. "Another Energy Year Book of Pakistan", Ministry of Petroleum and Natural Resources (MNPR), Islamabad Pakistan, 2014-2015.

6. Asif M., Muneer T., "Energy Supply, Its Demand and Security Issues for Developed and Emerging Economies", Renewable and Sustainable Energy Reviews, Vol. 11, No. 7, pp, 1388-1413, 2007.

7. Mirjat N.H., Uqaili M.A., Harijan K., Valasai G.D, Shaikh F., Waris M., "A Review of Energy and Power Planning and Policies of Pakistan", Renewable Sustainable Energy Reviews, Vol. 79, pp, 110-127, 2017.

8. Valasai G. D., Uqaili M. A., Memon H. R., Samoo S. R., Mirjat N. H., Harijan K., "Overcoming Electricity Crisis in Pakistan: A Review of Sustainable Electricity Options", Renewable and 
Sustainable Energy Reviews, Vol. 72, pp, 734745, 2017.

9. "Energy year book of Pakistan", (2012-2013). Ministry of Petroleum and Natural Resources (MNPR), Islamabad Pakistan, 2012-2013.

10. "British Petroleum (B.P), Statistical Review of World Energy", 2016.

11. "Energy year book of Pakistan, Ministry of Petroleum and Natural Resources (MNPR)", Islamabad Pakistan, 2015-2016.

12. Akhtar J., Yaqub M.I., Iqbal J., Sheikh N., Saba T., "Way Forward in Meeting Energy Challenges in Pakistan", International Journal of Ambient Energy, Vol. 39, No. 8, pp, 904-908, 2018.

13. Shar A. M., Mahesar A. A., Memon K. R., "Could Shale Gas Meet Energy Deficit: Its Current Status and Future Prospects", Journal of Petroleum Exploration and Production Technology, pp, 111, 2017.

14. https://www.pbc.org.pk/wpcontent/uploads/Towards-Pakistanu2019sEnergy-Security-and-Competitiveness.pdf. [Last accessed on $13^{\text {th }}$ February 2019].

15. Naik G. C., Tight Gas Reservoirs-An Unconventional Natural Energy Source for the Future", Technical Report, Available at https://www.sublettewyo.com/DocumentCenter/ View/358/tight_gas1?bidId=, 2008. [Last accessed on $10^{\text {th }}$ February 2019].

16. Holditch S. A., "Tight Gas Sands", Journal of Petroleum Technology, Vol. 58, No. 6, pp, 86-93 2006.

17. Dennis D., "Overview of Tight-Gas Field Development in the Middle East and North Africa Region", Journal of Petroleum Technology, Vol. 62, No. 10, pp, 52-54, 2010.

18. Alam S., "Potential of Tight Gas in Pakistan: Productive, Economic and Policy Aspects", Proceedings of the Annual Technical Conference of Pakistan Association of Petroleum Geoscientists (PAPG), Islamabad, 2010.

19. "Energy Information Administration (EIA)", International Energy Agency Statistics, 2011.
20. "Energy Information Administration (EIA 2013)", Annual energy Outlook. U.S Energy Information Administration, Washington.

21. Minstry of Petroleum and Natural Resources Energy Wing. http://www.mpnr.gov.pk.

22. "Tight Gas (Exploration \& Production) Policy2011 ", Government of Pakistan, Ministry of Petroleum and Natural Resources.

23. Majeed A., Mahesar A.A., "Pakistan's Kirthar Fold Belt Tight Gas Reservoirs Show Development Potential", Oil and Gas Journal, Vol. 114, 2016.

24. Ali H.S., Siddiqui T.F., "An Overview on Unconventional Gas Resources: Future of Pakistan", Bahria University Research Journal of Earth Sciences, Vol. 2, No. 1, pp, 52-60, 2017.

25. http://nedians.ning.com/profiles/blogs/unconvent ional-gas-production-marks-new-milestone-forpakistan [Last accessed on $15^{\text {th }}$ March, 2019].

26. http://www.juraenergy.com/our-assets/zarghunsouth.aspx [Last accessed on 27 $7^{\text {th }}$ March 2019].

27. https://www.dawn.com/news/1380204. [Last accessed on 27 March 2019].

28. http://www.juraenergy.com/media/12368/20141 112update_on_production_from_zarghun_south. pdf [Last accessed on 28 ${ }^{\text {th }}$ March 2019].

29. "Pakistan Petroleum \& Exploration Policy", Ministry of Petroleum and Natural resources of Pakistan (MNPR), 2012.

30. https://www.sdpi.org/publications/files/Pakistan $\% 20$ Energy\%202035FINAL\%2020th\% 20October\%202014.pdf [Last accessed on $21^{\text {st }}$ March 2019].

31. Pi G., Dong X., Dong C., Guo J., Ma Z., "The Status, Obstacles and Policy Recommendations of Shale Gas Development in China", Sustainability, Vol. 7, No. 3, pp, 2353-2372, 2015.

32. Mahesar A.A., Shar A.M., Memon K.R., Baladi S.A., "Experimental Study on Gas Slippage of Tight Gas Sands in Kirthar Fold Belt Sindh, Pakistan", Mehran University Research Journal of Engineering and Technology, Vol. 36, No. 3, pp, 719-732, 2017. 